\title{
COMMENTARY
}

\section{Sex and severe sepsis}

\author{
Bertrand Guidet*1-3 and Eric Maury'-3 \\ See related research by Sakr et al., http://ccforum.com/content/17/2/R50
}

\begin{abstract}
Epidemiological studies document that males are more prone than females to develop severe sepsis and this is confirmed by Sakr and colleagues in the previous issue of Critical Care. However, the impact of gender on prognosis of severe sepsis is a matter of debate. Sakr and colleagues report a higher mortality in septic females than in males. This puzzling result might be explained by confounding factors such as age, nosocomial infections, follow-up period, and case mix. The impact of sexual hormones in older females is less relevant. Treatments aimed at modifying sexual hormone profile are promising but need to be tested in future trials.
\end{abstract}

In the previous issue of Critical Care, Sakr and colleagues [1] reported an epidemiologic study they performed in 24 intensive care units (ICUs) in the Piedmont region of Italy. The study documents a lower prevalence of severe sepsis (SS) but a higher ICU mortality in females than in males.

The study's results on outcome are puzzling. Most previous studies report either no effect of gender or a protective effect of being a female. Several confounding factors might account for this result: the number of included patients with SS was small (305, including only 85 females), the period of inclusion during spring and summer induced a seasonal bias with different sources of SS as compared with winter, the percentage of ICUacquired SS was high (61\% in females), and females with SS were significantly older than males (67.7 versus 63.1 years); only 12 female patients were younger than 50 years of age. The median length of stay was short, precluding an interpretation of the Kaplan-Meier curve. No information on hospital or long-term outcome is

*Correspondence: bertrand.guidet@sat.aphp.fr

'AP-HP, Hôpital St Antoine, Réanimation médicale, 184 rue du Faubourg

Saint-Antoine, Paris, F-75012 France

Full list of author information is available at the end of the article provided. Studies with long-term follow-up have shown that male gender was associated with a worse prognosis. Weycker and colleagues [2] reported 5-year mortality rates of $77.5 \%$ in males and $70.2 \%$ in females. Also, it should be noted that the global incidences of SS for the whole population $(7.8 \%)$ and for females (6\%) were low and that ICU mortality rates for all patients $(51.1 \%)$ and for females (63.5\%) were very high given the values of simplified acute physiology score (SAPS) and Sequential Organ Failure Assessment (SOFA).

SS has been identified as a major factor in ICU bed occupancy, ICU cost, and ICU mortality [3-6]. The incidence of SS and septic shock is increasing over time [5-8] because of better diagnostic tools or refined definition [9] but more importantly because of change in case mix (older patients and patients with comorbidities and immunosuppression). The ICU population is getting older, and the sex ratio is in favor of females after 80 $[10,11]$. Moreover, immunosenescence might explain the higher incidence of SS in older patients [12], and atypical clinical presentation might increase the delay of diagnosis and treatment, both contributing to a higher mortality in older patients [11]. Since female patients were older than males in the study by Sakr and colleagues, age might have contributed to the higher mortality in female patients.

The impact of gender on prognosis may be related to sexual steroid hormone, although the contribution of young females ( $<50$ years) to the whole population of SS is small (only 12 out of 85 female patients). In fact, numerous animal experiments suggest that gender may influence outcome and that a better outcome can be observed when hormonal status is orientated toward a female phenotype. During experimental hemorrhagic shock in male rats, outcome is improved by the administration of testosterone blocker or by castration [13]. In the same model, the outcome of female mice is improving when circulating estrogens are at their maximal values (that is, during the prelutenizing phase) [14]. When proestrus and ovariectomized rodents are subjected to sepsis by cecal ligation and puncture after trauma-hemorrhage, ovariectomized mice exhibit a significantly higher death rate. Finally, in this animal model, estrogen administration in males and ovariectomized females prevents immune function impairment 
(assessed by interleukin-1 and interleukin-6 macrophage production) and cardiac contractility decreases. Similar results have been observed in experimental endotoxic challenge in rats [15]. An intravenous endotoxic bolus decreases blood pressure in male rats, but blood pressure is not modified in female animals. Interestingly, this deleterious effect of endotoxin in male rats is abolished by prior surgical castration [15].

Several clinical studies report increased estradiol levels in male patients with septic shock whereas circulating testosterone levels were dramatically decreased. In a preliminary observational survey performed in our ICU, circulating estradiol levels, measured during the first three days following ICU admission, were dramatically increased (reaching about six times the control levels) in a cohort of 40 male patients with SS or septic shock (unpublished data). Moreover, circulating estradiol values correlated with SAPS II, and the highest levels were observed in the most severe patients (patients with shock or with a fatal outcome). Mean circulating testosterone levels were dramatically decreased (reaching only a third of normal lower value) and never reached the minimal normal value of healthy men. Patients with shock had the lowest testosterone levels, but measured testosterone values did not differ according to outcome.

Given these clinical observations, it seems that sexual hormonal pattern among male patients with SS is adaptative in order to minimize deleterious effects of testosterone. There is little room, if any, for testosterone blockade. A sexual hormonal therapeutic modulation in SS and septic shock aimed at increasing circulating estradiol levels is appealing. This hypothesis needs to be assessed through randomized controlled trials.

\section{Abbreviations}

ICU, intensive care unit; SAPS, simplified acute physiology score; SS, severe sepsis.

\section{Competing interests}

The authors declare that they have no competing interests.

\section{Author details}

'AP-HP, Hôpital St Antoine, Réanimation médicale, 184 rue du Faubourg SaintAntoine, Paris, F-75012 France. ${ }^{2}$ Université Pierre et Marie Curie-Paris 6, UMR S U707, Paris, F-75012 France. ${ }^{3}$ INSERM, UMR S U707, Faculté de médecine SaintAntoine, 27 rue de Chaligny, Paris, F-75012 France.
Published: 15 May 2013

\section{References}

1. Sakr Y, Elia C, Mascia L, Barberis B, Cardellino S, Livigni S, Fiore G, Filippini C, Ranieiri VM: The influence of gender on the epidemiology of and outcome from severe sepsis. Crit Care 2013, 17:R50.

2. Weycker D, Akhras KS, Edelsberg J, Angus DC, Oster G: Long-term mortality and medical care charges in patients with severe sepsis. Crit Care Med 2003, 31:2316-2321.

3. Angus DC, Linde-Zwirble WT, Lidicker J, Clermont G, Carcillo J, Pinsky MR: Epidemiology of severe sepsis in the United States: analysis of incidence, outcome, and associated costs of care. Crit Care Med 2001, 29:1303-1310.

4. Brun-Buisson C, Meshaka P, Pinton P, Vallet B; EPISEPSIS Study Group: EPISEPSIS: a reappraisal of the epidemiology and outcome of severe sepsis in French intensive care units. Intensive Care Med 2004, 30:580-588.

5. Dombrovskiy VY, Martin AA, Sunderram J, Paz HL: Rapid increase in hospitalization and mortality rates for severe sepsis in the United States: a trend analysis from 1993 to 2003. Crit Care Med 2007, 35:1244-1250.

6. Guidet B, Aegerter P, Gauzit R, Meshaka P, Dreyfuss D, on behalf of the CUBRéa Study Group: Incidence and impact of organ dysfunctions associated with sepsis. Chest 2005, 127:942-951.

7. Martin G, Mannino DM, Eaton S, Moss M: The epidemiology of sepsis in the United States from 1979 through 2000. N Engl J Med 2003, 348:1546-1554.

8. Annane D, Aegerter P, Jars-Guincestre MC, Guidet B, for the CUB-Réa Network. Current epidemiology of septic shock. Am J Respir Crit Care Med 2003, 168:165-172.

9. Dellinger RP, Levy MM, Rhodes A, Annane D, Gerlach H, Opal SM, Sevransky JE, Sprung CL, Douglas IS, Jaeschke R, Osborn TM, Nunnally ME, Townsend SR, Reinhart K, Kleinpell RM, Angus DC, Deutschman CS, Machado FR, Rubenfeld GD, Webb SA, Beale RJ, Vincent JL, Moreno R; Surviving Sepsis Campaign Guidelines Committee including the Pediatric Subgroup: Surviving Sepsis Campaign: International Guidelines for Management of Severe Sepsis and Septic Shock: 22012. Crit Care Med 2013, 41:580-637.

10. Boumendil A, Angus DC, Guitonneau AL, Menn AM, Ginsburg C, Takun K, Davido A, Masmoudi R, Doumenc B, Pateron D, Garrouste-Orgeas M, Somme D, Simon T, Aegerter P, Guidet B; ICE-CUB study group: Variability of intensive care admission decisions for the very elderly. PLoS One 2012, 7:e34387.

11. Martin GS, Mannino DM, Moss M: The effect of age on the development and outcome of adult sepsis. Crit Care Med 2006, 34:15-21.

12. Gomez RC, Boehmer DE, Kovacs JE: The aging innate immune system. Curr Opin Immunol 2005, 17:457-462.

13. Angele MK, Wichmann MW, Ayala A, Cioffi WG, Chaudry $\mathrm{H}$ : Testosterone receptor blockade after hemorrhage in males. Arch Surg 1997, 132:1207-1214.

14. Jarrar D, Wang P, Cioffi WG, Bland Kl, Chaudry $\mathrm{H}$ : The female reproductive cycle is an important variable in the response to trauma-hemorrhage. Am J Physiol Heart Circ Physiol 2000, 279:H1015-H1021.

15. Losonczy G, Kriston T, Szabó A, Müller V, Harvey J, Hamar P, Heemann U, Baylis C: Male gender predisposes to development of endotoxic shock in the rat. Cardiovasc Res 2000, 47:183-191.

doi:10.1186/cc12690

Cite this article as: Guidet B, Maury E: Sex and severe sepsis. Critical Care 2013, 17:144. 